that could be attained depended on the thickness of the frozen shell that could be developed during the time that the steel was in the water cooled copper mold. This shell thickness appears to be a function of the amount of heat that can be extracted by the mold cooling water. This study indicated that for the $24 \times 6 \frac{1}{2}$ in. section that was used in most of the work covered in this report it was necessary to develop a shell thickness of at least about 0.4 in. as the section emerged from the mold. This limiting shell thickness could be attained by casting less than 1400 $\mathrm{lb}$ of steel per min. When the casting rate exceeded such limiting values, severe longitudinal corner cracking was encountered in the outer surface and, even more serious, there was a definite hazard of metal breaking through the shell.

A general discussion was presented of the factors other than casting speed which could influence the capacity of a given continuous casting plant. It was shown that while a rather fixed tonnage could be expected for the plant capacity, there were other factors, such as the type of steelmaking units supplying steel to the casting plant, the number of steelmaking furnaces, and the general arrangement of the facilities which exerted pronounced effects on the ability to attain high long term production rates.

This paper presents results obtained in the limited number of tests carried out on one type of continuous casting facility operated in conjunction with electric furnaces. The study was somewhat unique in that the slab sections cast were larger than any reported to date. Other casting schemes are currently in successful operation, and it is very likely that the results that would be obtained on alterna- tive equipment and on other carbon steels would differ from those covered in this paper. In addition, there will undoubtedly be future developments that will extend the limits and increase the productive capacity of the continuous casting process.

\section{References}

${ }^{1} \mathrm{H}$. Bessemer: U. S. Patent No. 49053, 1865.

2 Messingwerk Schwarzwald A. G.: German Patent No. 510361, 1930 .

3 Babcock and Wilcox Tube Co.: U. K. Patent No. 586,030.

4 M. V. M. Jacquet: U. K. Patent No. $540,276$.

5 British Iron and Steel Research Assoc.: U. K. Patent Application No. 715,282 .

${ }_{6}^{6} \mathrm{H}$. G. DeYoung: Pioneering in New Developments in a specialty

steel mill. AISI Yearbook, 1955, pp. 201-248. lum Steel Corp. Blast Furnace and Steel Plant, 1953, vol. 11, pp. 1301-1306.

8 J. Savage: Application of continuous casting to steel. Metal Treatment and Drop Forging, 1955, pp. 277-287.

$9 \mathrm{~J}$ Savage and W. H. Pritchard: The problem of rupture of the billet in the continuous casting of steel. Journal Iron and Steel Institute, 1954, vol. 178, pp. 269-276.

10 D. M. Lewis and J. Savage: The principles of continuous casting of metals. Metallurgical Reviews Institute of Metals, 1956, vol. $11 \mathrm{~K}$. G. Speith and A. Bungeroth: The continuous casting of steel by the Junghaus Method. Stahl und Eisen, 1952, vol. 72, pp. 869-885. $12 \mathrm{~K}$. G. Speith and A. Bungeroth: The development of the vertical continuous casting of steel. Stahl und Eisen, 1956, vol. 76, pp. 437-441.

${ }_{13} \mathrm{H}$. Kramer and B. Tarmann: The solidification of steel during continuous casting. Stahl und Eisen, 1949, vol. 69, pp. 813-819.

14 R. Fievet: Continuous casting at Anciens Etablissement Cail. Presented to Soc. of Civil Engineers of France, 1956.

${ }_{15}$ M. S. Boichenko and V. S. Rutes: Continuous casting of steel. Liternol Proizvodstvo, 1956, vol. 3, pp. 1-4.

${ }_{16}$ M. S. Boichenko, V. S. Rutes, and N. A. Nicholayev: Development and adaptation of the continuous casting process for steel. Stal, 1956, vol. 16, pp. 505-513.

17 N. L. Komandin: Investigation of the properties of continuously cast billets. Stal, 1956, vol. 16, pp. 307-317.

18 V. S. Rutes and A. Pronov: Conference in the continuous casting of steel. Stal, 1956, vol. 16, pp. 263-265.

${ }_{10} \mathrm{~W}$. W. Jacobs: Development of continuous casting at Atlas teels Ltd. Iron and Steel Engineer, 1956, vol. 33, pp. 89-92. 1956. Iron and Steel Engineer, 1957, vol. 34, p. 143.

Discussion of this paper sent (2 copies) to AIME by Oct. 1, 1957 will appear in AIME Transactions Vol. 212, 1958, and in JourNaL of METALS, October 1958 .

Technical Note

\title{
Sigma Phases Containing Osmium and Iridium
}

\author{
by M. V. Nevitt and J. W. Downey
}

$\mathrm{D}$ URING the course of the present investigation of alloy phases involving transition metals, $\sigma$ phases were found in the systems Os-Ta, Os-W, and

Table I. Approximate Composition Range and Lattice Parameters of Several $\sigma$ Phases

\begin{tabular}{|c|c|c|c|c|}
\hline \multirow[b]{2}{*}{ System } & \multirow{2}{*}{$\begin{array}{c}\text { Approximate } \\
\text { Composition } \\
\text { Range, Atomic } \\
\text { Pct, at 1200 } 100^{\circ} \mathbf{C}\end{array}$} & \multicolumn{3}{|c|}{ X-Ray Data } \\
\hline & & $\begin{array}{l}\text { Alloy Compo- } \\
\text { sition, Atomic } \\
\text { Pet }\end{array}$ & $a_{0}, \mathbf{A}$ & $\mathbf{c}_{0}, \mathbf{A}$ \\
\hline $\begin{array}{l}\text { Os-W } \\
\text { Os-Ta } \\
\text { Ir-Ta }\end{array}$ & $\begin{array}{l}65 \text { to } 67 \mathrm{~W} \\
65 \text { to } 75 \mathrm{Ta} \\
75 \text { to } 85 \mathrm{Ta}\end{array}$ & $\begin{array}{l}67 \mathrm{~W}, 33 \mathrm{Os} \\
75 \mathrm{Ta}, 25 \mathrm{Os} \\
75 \mathrm{Ta}, 25 \mathrm{Ir}\end{array}$ & $\begin{array}{l}9.686 \\
9.934 \\
9.938\end{array}$ & $\begin{array}{l}5.012 \\
5.189 \\
5.172\end{array}$ \\
\hline
\end{tabular}

Ir-Ta. The (Os, W) $\sigma$ phase was also recently reported by Raub. ${ }^{1}$ Pertinent information is given in Table I. The approximate composition range of sta-

M. V. NEVITT, Member AIME, and J. W. DOWNEY are associated with the Metallurgy Div., Argonne National Laboratory, Lemont, III.

TN 429E. Manuscript, Apr. 11, 1957. bility was determined metallographically on arcmelted buttons that were annealed $72 \mathrm{hr}$ at $1200^{\circ} \mathrm{C}$ and water quenched. X-ray powder patterns were obtained with a $114.6 \mathrm{~mm}$ diam powder camera using filtered copper radiation.

The composition for (Os, W) $\sigma$ given by Raub (66 atomic pct $\mathrm{W}$ ) is in agreement with the composition range reported here. However, the lattice constants reported by Raub are: $a_{0}=9.913 \pm 0.007, c / a=0.515$. The reason for the discrepancy between the lattice constants reported by Raub and those given here is not known.

\section{Acknowledgments}

The authors wish to thank M. H. Mueller and $\mathrm{H}$. W. Knott for assistance with the X-ray diffraction work, and R. A. Morris for the preparation of the alloys. This paper is based upon work performed at the Argonne National Laboratory under the auspices of the Atomic Energy Commission.

\section{Reference}

1 E. Raub: Die Osmium-Chrom-Legierungen. Ztsch. für Metallkunde, 1957, vol. 8, p. 53 . 